\title{
Electrochemical Behavior of Vitreous Glass Carbon and Platinum Electrodes in the Ionic Liquid 1-n-Butyl-3-Methylimidazolium Trifluoroacetate
}

\author{
Paulo A. Z. Suarez, Crestina S. Consorti, Roberto F. de Souza, Jairton Dupont and Reinaldo S. Gonçalves*
}

Instituto de Química, Universidade Federal do Rio Grande do Sul, Av. Bento Gonçalves, 9500, 91501-970, Porto Alegre - RS, Brazil

\begin{abstract}
A janela eletroquímica do líquido iônico trifluoroacetato de 1-n-butil-3-metilimidazólio foi estudada sobre eletrodos de carbono vítreo e platina em condições estática e dinâmica. Observouse uma drástica diminuição da janela eletroquímica ao trocar o eletrodo de carbono vítreo $(4.50$ V) pelo de platina $(2.50 \mathrm{~V})$. A variação da velocidade de rotação do eletrodo e da velocidade de varredura não afetaram o perfil dos voltamogramas, porém alteraram as densidades de corrente dos picos referentes aos processos anódicos e catódicos. A adsorção do cátion imidazólio durante o processo de transferência de carga na região catódica foi evidenciada, principalmente para baixas velocidades de rotação do eletrodo.

The 1-n-butyl-3-methylimidazolium trifluoroacetate ionic liquid electrochemical windows have been investigated at vitreous carbon and platinum disc electrodes under static and dynamic conditions. The electrochemical window abruptly decreases by changing vitreous carbon (4.50 $\mathrm{V})$ by platinum electrode $(2.50 \mathrm{~V})$. Electrode rotation and potential sweep rate did not affect the current-potential profiles but alter the current values of both anodic and cathodic peaks. The adsorption of imidazolium cation involved in the charge transfer process during the cathodic sweep rate was evidenced, mainly at low electrode rotation.
\end{abstract}

Keywords: platinum electrode, vitreous carbon electrode, ionic liquid, imidazolium cation

\section{Introduction}

Room temperature molten salts or ionic liquids have been historically considered as liquid electrolytes composed entirely of ions. However, new evidences in the last years pointed out that these compounds, specially those based upon N,N'-dialkyl substituted imidazolium cations, are better described as liquid compounds that display ioniccovalent structures. ${ }^{1}$ In the light of their promising physical and chemical properties, room temperature ionic liquid systems attract increasing attention for applications as solvents in organic synthesis, transition metal two-phase catalysis, liquid-liquid extraction and electrochemical devices. ${ }^{1-3}$ Some characteristics that make these liquids so versatile and promising as novel solvents are (i) the high thermal stability and wide range of liquid phase, ${ }^{4}$ (ii) their ability to act as solvents for many organic and inorganic materials, since it has been shown that they have micro heterogeneities that induce to act either as highly or weakly polar liquids, ${ }^{5}$ (iii) the considerable conductivity, which

\footnotetext{
* e-mail: reinaldo@if.ufrgs.br
}

commends their use in the study of electrochemical processes without using supporting electrolytes, and (iv) the negligible vapor pressure in contrast with conventional organic solvents, permitting their study under conditions of high vacuum. From the ecological point of view, the easier recovery of these solvents and its negligible vapor pressure, which avoid vapor emissions, makes these solvents environmental friendly. ${ }^{1}$

We have recently showed that the ionic liquids obtained from the combination of 1-n-butyl-3-methylimidazolium cation with tetrafluoroborate and hexafluorophosphate are fluid within a wide range of temperature ${ }^{6}$ and possess an enlarged electrochemical window (up to $7.00 \mathrm{~V}$ ). ${ }^{7} \mathrm{In}$ particular, the large electrochemical window offers the use of these ionic liquids as unique solvents for electrochemical and spectroscopic investigations.

Herein we report the electrochemical behavior of vitreous glass carbon and platinum electrodes in the 1-nbutyl-3-methylimidazolium trifluoroacetate ionic liquid. In order to characterize the electrochemical window and the electrochemical processes that occur on the electrode surface, some variables were investigated. The main 
electrochemical technique used in this work was cyclic voltammetry under static and dynamic conditions.

\section{Experimental}

\section{Electrochemical experiments}

A home made electrochemical cell with 3 electrodes was used. A platinum disc (length $3 \mathrm{~mm}, 1 \mathrm{~mm}$ diameter) immersed in the solvent as a quasi-reference electrode $(\mathrm{PQRE})^{8}$ and a platinum wire as auxiliary electrode were used. Working electrodes were either a platinum disc $(\mathrm{r}=1 \mathrm{~mm})$ or a vitreous carbon disc $(\mathrm{r}=2.3 \mathrm{~mm})$ rotating electrode (RDE). The RDE were polished with alumina to a mirror-like surface, cleaned with $8 \mathrm{~mol} \mathrm{~L}^{-1}$ aqueous $\mathrm{HNO}_{3}$, sonicated in distilled water, washed with acetone, dried under vacuum and then left in contact with the solvent for at least $12 \mathrm{~h}$ before use. The ionic liquid, with highly purity, was used without addition of supporting electrolyte.

Current-potential curves in the solvent were obtained with a Microquimica potentiostat, model MQPG01, coupled to a personal computer. RDE rotation was performed using an EG\&G Rotor analytical rotator, model 616. Measurements were carried out at room temperature. Only the first voltammogram was considered in this paper, however, a previous potential program was applied to the electrode in order to get the same I(E) profile.

\section{Synthesis of 1-n-butyl-3-methylimidazolium trifluoroacetate ${ }^{9}$}

An one necked round bottomed flask was charged with $36.98 \mathrm{~g}(0.21 \mathrm{mmol})$ of finely powdered 1- $n$-butyl-3methylimidazolium chloride, prepared according to literature procedures, ${ }^{10} 24.17 \mathrm{~g}(0.21 \mathrm{mmol})$ of trifluoroacetic acid, used as purchased, and $100 \mathrm{~mL}$ of distillated water. The reaction mixture was stirred at room temperature for $15 \mathrm{~min}$ and then $8.48 \mathrm{~g}(0.21 \mathrm{mmol})$ of sodium hydroxide was added and left stirring for $2 \mathrm{~h}$, affording an heterogeneous mixture. The water was removed under reduced pressure $(0.1 \mathrm{mbar})$ at $50{ }^{\circ} \mathrm{C}$ until constant weight. To the remaining suspension $100 \mathrm{~mL}$ of dichloromethane and $35 \mathrm{~g}$ of anhydrous magnesium sulfate were added. After $1 \mathrm{~h}$ standing, the suspension was filtered and the volatiles were removed under reduced pressure $(0.1 \mathrm{mbar})$ at $30{ }^{\circ} \mathrm{C}$ for $2 \mathrm{~h}$ affording $40.06 \mathrm{~g}(0.17 \mathrm{mmol}, 83 \%)$ of 1- $n$-butyl-3methylimidazolium trifluoroacetate as a light yellow viscous liquid. $\mathrm{Tg}=-45{ }^{\circ} \mathrm{C} .{ }^{1} \mathrm{H}$ NMR (acetone- $\mathrm{D}_{6}$, ppm relative to TMS): 9.82 (s, 1H); $7.74(\mathrm{t}, 1 \mathrm{H}, J 2.1 \mathrm{~Hz}) ; 7.71(\mathrm{t}, 1 \mathrm{H}, J$ $2.1 \mathrm{~Hz}) ; 4.39$ (t, 2H, J 9.2 Hz); $4.11(\mathrm{~s}, 3 \mathrm{H}) ; 1.93(\mathrm{~m}, 2 \mathrm{H})$; $1.35(\mathrm{~m}, 2 \mathrm{H}) ; 0.93(\mathrm{t}, 3 \mathrm{H}, J 9.1 \mathrm{~Hz})$.

\section{Results and Discussion}

Figure 1 shows the voltammogram of the vitreous carbon in the ionic liquid at sweep rate of $0.05 \mathrm{Vs}^{-1}$ and $\omega=400$ $\mathrm{rpm}$. Experiments were made in the electrochemical window between $-3.50 \mathrm{~V}$ and $1.00 \mathrm{~V}$. In this potential range, small cathodic currents were observed during the cathodic sweep. This charge transfer process should be related with the electroreduction of the imidazolium cation. In the anodic sweep, noticeable anodic current values were observed at $0.25 \mathrm{~V}$. This process may be related with the electroactivity of the melt, suggesting a decomposition of the anion. In the potential range between $-0.50 \mathrm{~V}$ and $-3.00 \mathrm{~V}$, practically no charge transfer reactions on the electrode surface were observed. Small current values recorded may be associated with the double layer charging and/or other processes. This large electrochemical window without charge transfer processes shows a promising property to be used in the electroreduction studies.

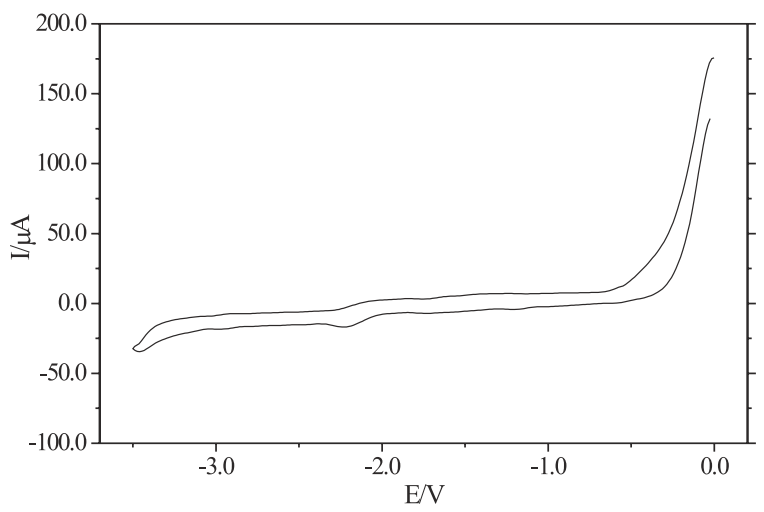

Figure 1. Voltammogram of vitreous carbon in 1-n-butyl-3methylimidazolium trifluoroacetate at $\mathrm{v}=0.05 \mathrm{Vs}^{-1}$ and $\mathrm{w}=400 \mathrm{rpm}$.

Another interesting fact to be pointed out it is observed in the Figure 2, where the same experiment was repeated by keeping the working electrode under static conditions. Cathodic current values increase at more negative potential values. This fact may be explained considering that the concentration of the electroactive species involved in the cathodic process on the electrode surface increases when the system was kept static. This effect suggests that an adsorption process of the electroactive species should be involved in the interaction with the electrode surface. The most probably electrochemical reaction that may be occurring on the electrode surface is depicted in Scheme 1.

At $-1.00 \mathrm{~V}$ a small anodic peak appears in the anodic sweep. This should indicate a charge transfer process associated with the electrooxidation of an adsorbed species formed previously at more negative potential that probably 


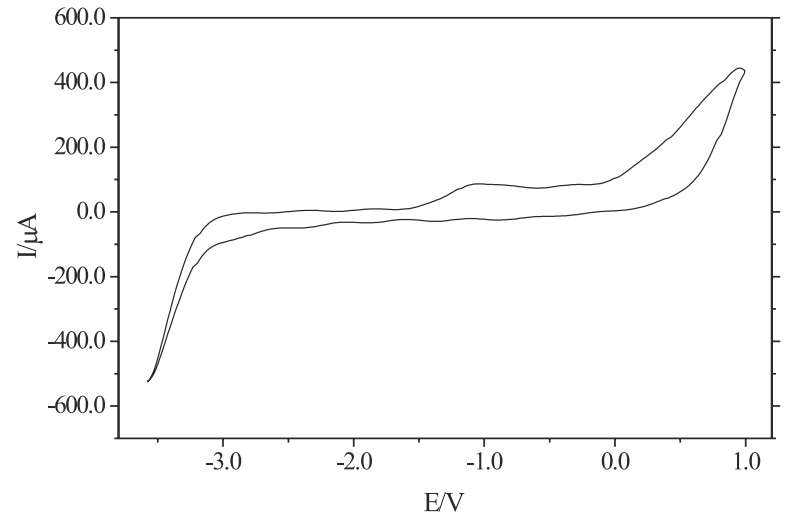

Figure 2. Voltammogram of vitreous carbon in 1-n-butyl-3methylimidazolium trifluoroacetate at $\mathrm{v}=0.05 \mathrm{Vs}^{-1}$ and static condition.

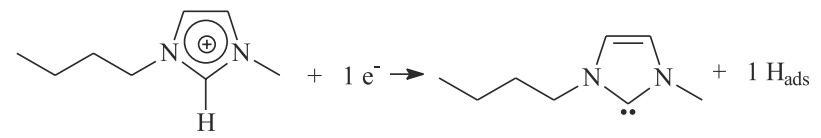

Scheme 1. Proposed electrochemical reduction mechanism of 1- $n$-butyl-3-methyl-imidazolium trifluoroacetate.

starts at $-2.2 \mathrm{~V}$. These one are probably related with the electrooxidation of the reduced species such as the radical imidazole and $\mathrm{H}_{\text {ads }}$ formed earlier, as suggested in Scheme 1. Adsorption of nitrogen heterocyclic unsaturated compounds has been reported on different metals. ${ }^{11-13}$ Indeed, a gas evolution in small amounts, probably molecular hydrogen, from the electrode surface was observed, which is in agreement with the electrochemical reaction proposed in Scheme 1. It is important to note that, when using rotating electrode this peak was not observed, probably due to the desorption of the adsorbed species and their diffusion away from the electrode.

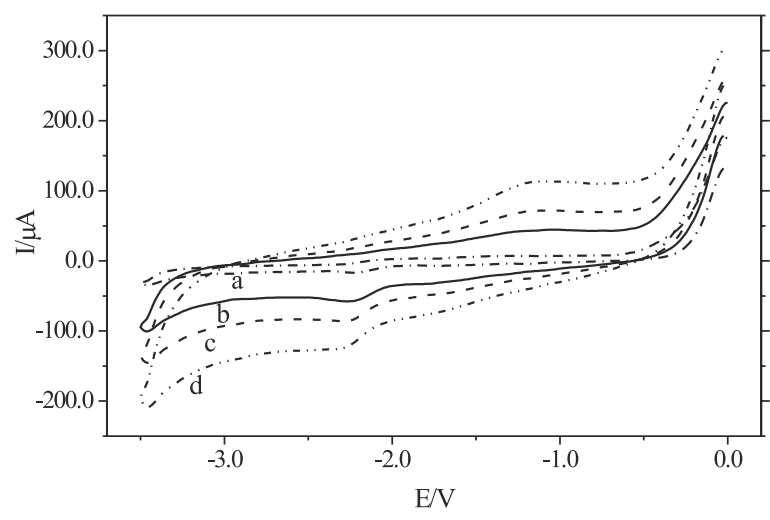

Figure 3. Sweep rate effect over voltammograms of vitreous carbon in 1- $n$-butyl-3-methylimidazolium trifluoroacetate at $\mathrm{w}=400 \mathrm{rpm}$. (a) $\mathrm{v}=$ $0.05 \mathrm{Vs}^{-1}$, (b) $\mathrm{v}=0.50 \mathrm{Vs}^{-1}$, (c) $\mathrm{v}=1.00 \mathrm{Vs}^{-1}$, (d) $\mathrm{v}=2.00 \mathrm{Vs}^{-1}$.

\section{Effect of the electrode rotation $(\omega)$}

This experiment was made in order to verify the effect of the electrode rotation on the voltammograms of vitreous carbon recorded at $0.05 \mathrm{Vs}^{-1}$. The electrochemical charge transfer processes were kept in the same potential range independently of $\omega$. However, the currents values of both anodic and cathodic processes increase with $\omega$, suggesting that they are under a diffusion control.

\section{Effect of the potential sweep rate ( $v)$}

The current/potential profiles for vitreous carbon electrode at different potential sweep rates are shown in Figure 3. The electrode rotation was kept constant at 400 $\mathrm{rpm}$. When increasing the sweep rate the intensity of the current peak increases also. However, the shoulder related with the electrooxidation of the adsorbed radical imidazole increases proportionally with $v$. This probably suggests that the same species are being formed on the electrode surface and the electrochemical behavior of the electrode was not affected by the potential sweep rate. In fact, this is also confirmed by observing that the potential values associated with the current peak remains constant when the sweep rate increases. On the cathodic scan these voltammograms exhibit well-defined current peaks, probably associated with electroreduction of the adsorbed species formed from the ionic liquid.

\section{Studies with platinum electrode}

The electrochemical behavior of platinum electrode, kept under static conditions, in 1- $n$-butyl-3-methylimidazolium trifluoroacetate is show in the Figure 4. The potential range studied was between $-3.50 \mathrm{~V}$ and $-1.00 \mathrm{~V}$,

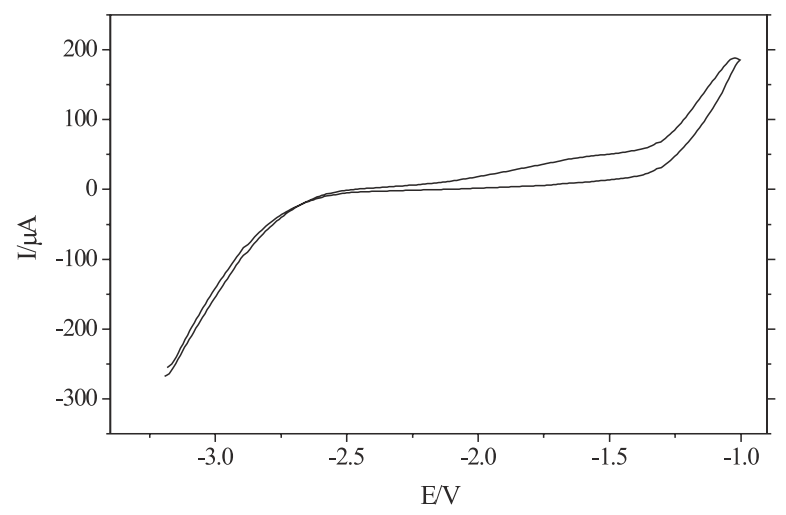

Figure 4. Voltammogram of platinum in 1- $n$-butyl-3-methylimidazolium trifluoroacetate at $\mathrm{v}=0.05 \mathrm{Vs}^{-1}$ and static condition. 
which is, comparatively, shorter than with vitreous carbon. Indeed, the electrochemical decomposition of the melts start at around $-1.30 \mathrm{~V}$, which is completely different by comparing with vitreous carbon electrode (around $0.00 \mathrm{~V}$ ). The catalytic activity of platinum may be responsible for this decrease in the electrochemical window. However, due to the similarity of $\mathrm{I}(\mathrm{E})$ curves, it is not unreasonable to suppose that analogous processes are probably involved in the limiting potentials.

\section{Conclusion}

In summary, we have shown that the 1-n-butyl-3methylimidazolium trifluoroacetate ionic liquid posses an increased electrochemical window, compared with other solvents described so far. The current-potential profiles did not show any changes on electrochemical mechanism with electrode rotation and potential sweep rate. However, these parameters alter the current values suggesting that the species related with both anodic and cathodic processes are under diffusion control. The adsorption of imidazolium cation involved in the charge transfer process during the cathodic sweep was evidenced, mainly at low electrode rotation rate. The electrochemical window abruptly decreases by changing vitreous carbon by platinum electrode in this ionic liquid, probably due to the catalytic activity of the metal.

\section{Acknowledgements}

Financial support by FAPERGS and CNPq is gratefully acknowledged. C.S.C. expresses her appreciation for a fellowship from CAPES.

\section{References}

1. Dupont, J.; Consorti, C. S.; Spencer, J.; J. Braz. Chem. Soc. 2000, 11, 337.

2. Welton, T. Chem. Rev. 1999, 99, 2071.

3. Wasserscheid, P.; Keim, W.; Angew. Chem. Int. Ed. 2000, 39, 3773.

4. Ngo, H. L.; LeCompte, K.; Hargens, L.; McEwen, A. B.; Thermochim. Acta 2000, 357, 97.

5. Schröeder, U.; Wadhawan, J. D.; Compton, R. G.; Marken, F.; Suarez, P. A. Z.; Consorti, C. S.; de Souza, R. F.; Dupont, J.; New J. Chem. 2000, 24, 1009.

6. Suarez, P. A. Z.; Einloft, S.; Dullius, J. E. L.; de Souza, R. F.; Dupont, J.; J. Chim Phys. 1998, 95, 1626.

7. Suarez, P. A. Z.; Selbach, V. M.; Dullius, J. E. L.; Einloft, S.; Piatnicki, C. M.; Azambuja, D. S.; de Souza, R. F.; Dupont, J.; Electrochim. Acta 1997, 42, 2533.

8. Laity, R. W.; In Reference Electrodes; Ives, D. J. G.; Janz, G. J., Ed.; Academic Press: New York, 1961.

9. Bonhote, P.; Dias, A. P.; Papageorgiou, N.; Kalyanasundaram, K.; Gratzel, M.; Inorg. Chem. 1996, 35, 1168.

10. Wilkes, J. S.; Levisky, J. A.; Wilson, R. A.; Hussey, C. L.; Inorg. Chem. 1982, 21, 1263.

11. Gonçalves, R. S.; Olivera, W. X.; J. Braz. Chem. Soc. 1992, 3, 92.

12. Chagas, L. V.; Gonçalves, R. S.; Corrosion 1996, 52, 653.

13. Giacomini, N. P.; Gonçalves, R. S.; Anais Assoc. Bras. Quím. 1997, 46, 269. 